\title{
A Review of Obstetrical Outcomes and Complications in Pregnant Women after Bariatric Surgery
}

Yasmeen A. Haseeb

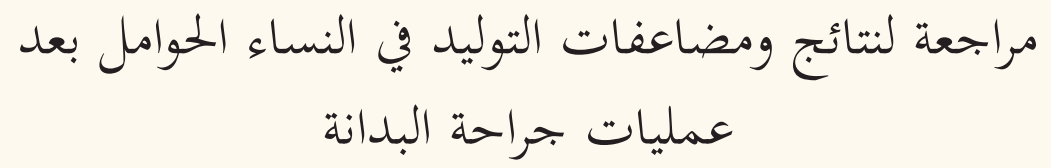

ياسمين اختر حسيب

ABSTRACT: Bariatric surgery (BS) is a novel treatment for weight reduction with longer lasting health benefits. This review aimed to summarise the available evidence regarding the fetomaternal outcomes and the most common challenges and complications in pregnancies following BS. Google Scholar (Google LLC, Mountain View, California, USA) and PubMed ${ }^{\circledR}$ (National Library of Medicine, Bethesda, Maryland, USA) databases were searched for articles published until December 2018. A total of 64 articles were included in this review and results showed that BS mitigates the risk of gestational diabetes mellitus, hypertensive disorders in pregnancy and fetal macrosomia. However, it can also have detrimental effects on fetomaternal health. There is paucity of data regarding small for gestational age intrauterine growth restriction, premature rupture of membranes and longterm effects on the children born to women who underwent BS.

Keywords: Bariatric Surgery; Nutritional Deficiencies; Obesity; Pregnancy; Surgical Injuries.

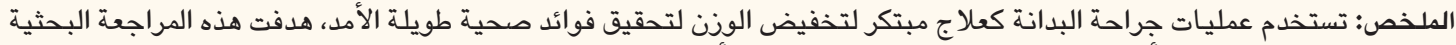

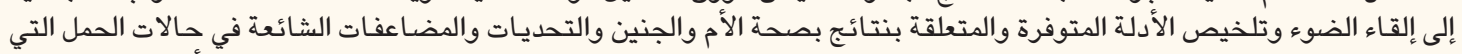

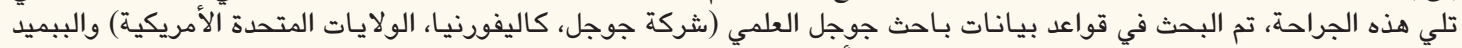

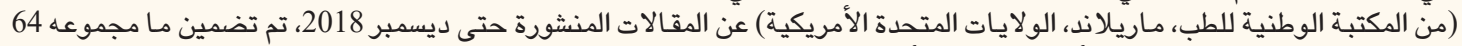

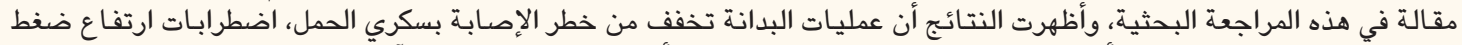

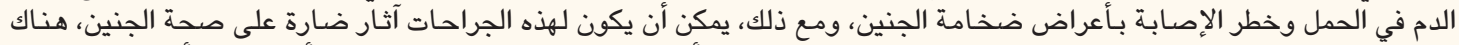

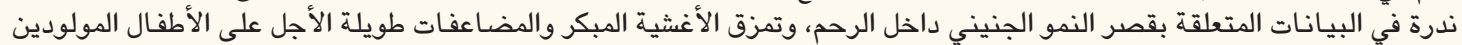
لنساء خضعوا لعمليات جراحة البدانة. الكلمات المفتاحية: جراحة البدانة؛ النقص الغذائي؛ السمنة؛ الحمل؛ الإصابـات الجراحية.

$\mathrm{T}$ He WORLD HEAlth ORganization (WHO) estimates that $13 \%$ of the world's population is suffering from obesity. ${ }^{1}$ In the UK, obesity rates have increased in women of reproductive ages from $24.2 \%$ in 2005 to $28.3 \%$ in 2015 . $^{2,3}$ The Centre for Maternal and Child Enquiries highlighted that obesity was responsible for 35\% of maternal mortality and 30\% of perinatal mortality from 2000 to $2003{ }^{4}$

Pregnant women with obesity have an increased risk of early pregnancy loss, hypertensive disorders in pregnancy, gestational diabetes mellitus (GDM), small for gestational age (SGA) newborns, difficult prolonged labour, increased caesarean section (CS) rates, thromboembolism, stroke, myocardial infarction and wound infections. ${ }^{5-9}$ The National Institute for Health and Clinical Evidence recommends bariatric surgery (BS) for women with a body mass index of $>40$ $\mathrm{kg} / \mathrm{m}^{2}{ }^{10}$ There are many research papers emphasising the fetomaternal benefits after undergoing BS. This paper aimed to summarise the most recent evidence about fetomaternal outcomes, maternal nutritional deficiencies and complications after BS and highlights areas for future research.

\section{Methods}

Google Scholar (Google LLC, Mountain View, California, USA) and PubMed ${ }^{\mathbb{R}}$ (National Library of Medicine, Bethesda, Maryland, USA) databases were used in this non-systematic and narrative review to search for publications only in English using a combination of keywords specific to the review's purpose. Considering the high variability in various sources of information, a descriptive synthetic approach was adopted to include 
articles published until December 2018. Studies with clearly defined inclusion and exclusion criteria and those that focused on pregnancies after BS addressing fetomaternal outcomes, nutritional deficiencies and complications of BS were included. Initially, a total of 220 articles were identified. Subsequently, the search was refined by using more specific keywords, either alone or in combination, such as "bariatric surgery", "pregnancy", "obstetrical outcome" and "medical complications" or "surgical complications". Finally, 64 articles were included in this review after screening to ensure their relevance to the topic.

\section{Results}

\section{PREGNANCY RELATED MEDICAL COMPL- ICATIONS AFTER BARIATRIC SURGERY}

Case-control, cohort studies and some case reports have shown that pre-conception BS is associated with a reduction of GDM and hypertension during pregnancy. ${ }^{11-13}$ Pre-conceptional BS is associated with shortand long-term fetomaternal complications during pregnancy-which include fetal anomalies, intrauterine growth restriction (IUGR), malnutrition, prolonged labour, increase in induction of labour, postpartum weight retention and juvenile obesity in children. ${ }^{14-16}$ However, pregnancies following BS may also be associated with many medical, surgical and obstetric morbidities. ${ }^{17,18}$

Weintraub et al's retrospective study, conducted at a tertiary care centre in Israel, studied the effect of BS on pregnancy outcome between 1988 and 2006. ${ }^{19}$ They analysed 301 pregnant women who had never had BS and 507 pregnant women after BS and showed that there was a significant reduction in GDM (17.3\% versus $11.0 \% ; P=0.009)$ and hypertension $(23.6 \%$ versus $11.02 \% ; P=0.001)$ in women after BS. ${ }^{19}$

Kwong et al.'s systematic review and meta-analysis of 17 cohort studies demonstrated that there was a reduction in hypertensive disorders in pregnancy (odds ratio [OR]: 0.57, confidence interval [CI]: 0.30-1.09), GDM (OR: 0.55, CI: 0.32-0.97) and fetal macrosomia (OR: 0.34, CI: 0.17-O.69) following BS. ${ }^{20}$ Luck et al. reported similar results with the addition of a costeffectiveness strategy for women with anovulation to improve their overall pregnancy rate. ${ }^{21}$

Johansen et al's study included 627,693 singleton pregnancies from the Swedish Medical Birth Registry from 2006 to 2011. Of the pregnant women, 670 had prior BS and this revealed a decrease in GDM $(1.9 \%$ versus $6.8 \%$, OR: 0.25 , CI: $0.13-0.18 ; P=0.001)$; the frequency of macrosomic fetuses were also reduced in this group (8.6\% versus $22.4 \%$, OR: 0.33 , CI: $0.24-0.44$; $P<0.001){ }^{22}$

Sheiner et al. reported a higher rate of hypertension in pregnancy $(5.4 \%$ versus $1.7 \% ; P<0.001)$ and GDM (9.4\% versus $5.0 \%$; $P=0.001)$ after BS; however, this association was insignificant on multiple logistic regression analysis..$^{23}$ Conversely, Patel et al. found no statistically significant difference in GDM and hypertension between pregnant women with and without BS. ${ }^{24}$

\section{PERINATAL OUTCOME AND CONGENITAL MALFORMATIONS}

Sheiner et al. described 298 deliveries after BS and compared the outcomes to a control group of 159,210 subjects from 1988 to $2002{ }^{23}$ There was no significant difference of perinatal mortality and congenital abnormalities between the two groups $(0.3 \%$ versus $1.5 \% ; P=0.10$ and $5.0 \%$ versus $4.0 \% ; P=0.355$, respectively). ${ }^{23}$ Dixon et al. studied 79 pregnancies after BS and reported one duodenal atresia and one stillbirth at 41 gestational weeks. ${ }^{25}$ Due to paucity of data in this regard, more research is needed to evaluate the risk of congenital malformations as some case reports have shown increased risk of neural tube defects after BS. ${ }^{26,27}$

There may be developmental delays in children born to women who had BS prior to their pregnancy. ${ }^{27}$ Johansson et al. studied long-term growth, neuropsychosomatic and speech development in children born to women after BS in Brazil. ${ }^{22}$ Speech developmental defects were seen in these children; however, this important observation requires more research and follow-up of children born after BS. ${ }^{22}$ Patel et al. and Cools et al. reported delays in speech, visual and neurological development in children born to women after BS. ${ }^{24,26}$ The results are presented in Table 1.

\section{PREMATURITY AND PREMATURE RUPTURE OF MEMBRANES}

There is no significant difference in premature births and premature rupture of membranes after BS compared to those who did not undergo BS..$^{24,25}$

Sheiner et al. found a positive correlation between premature rupture of membranes and BS (OR: 1.9; $P=0.001){ }^{23}$ The underlying mechanism is not fully understood and needs more research to elucidate this relationship.

\section{FETAL GROWTH AND BIRTH WEIGHT}

$B S$ has been found to be associated with reduction of fetal macrosomia (birth weight $>4,000 \mathrm{~g}$ ) ${ }^{26-28}$ Weintraub et al. demonstrated a significant reduction in macrosomia in pregnancies after BS versus women with 
Table 1: Summary of previous studies regarding obstetrical outcomes after bariatric surgery ${ }^{20-22,23,28,30,31,34,57,59,60}$

\begin{tabular}{|c|c|c|c|}
\hline $\begin{array}{l}\text { Author and year } \\
\text { of publication }\end{array}$ & $\begin{array}{l}\text { Significant positive changes } \\
\text { compared to control }\end{array}$ & $\begin{array}{l}\text { Significant negative } \\
\text { changes compared } \\
\text { to control }\end{array}$ & Conclusion \\
\hline $\begin{array}{l}\text { Kwong et al. } .^{0} \\
(2016)\end{array}$ & $\begin{array}{l}\text { - Lower GDM, HTN, PPH, } \\
\text { macrosomia and PE }\end{array}$ & $\begin{array}{l}\text { - Higher SGA, IUGR } \\
\text { and still birth }\end{array}$ & $\begin{array}{l}\text { BS can be helpful to reduce obstetrical complications } \\
\text { but is associated with increased risk of still births and } \\
\text { growth restriction. }\end{array}$ \\
\hline $\begin{array}{l}\text { Luck et al. } .^{21} \\
(2016)\end{array}$ & $\begin{array}{l}\text { - Lower GDM, PE and } \\
\text { macrosomia }\end{array}$ & $\begin{array}{l}\text { - Higher SGA, preterm } \\
\text { birth, CS, maternal } \\
\text { death and NND }\end{array}$ & $\begin{array}{l}\text { BS before pregnancy reduces many obstetrical compl- } \\
\text { ications and is a cost-effective strategy to improve the } \\
\text { pregnancy outcome for women who are anovulatory. }\end{array}$ \\
\hline $\begin{array}{l}\text { Johansson et al.22 } \\
\text { (2015) }\end{array}$ & $\begin{array}{l}\text { - Lower GDM, PE and } \\
\text { macrosomia }\end{array}$ & $\begin{array}{l}\text { - Higher NND, SGA } \\
\text { and CS }\end{array}$ & $\begin{array}{l}\text { BS is a cost-effective strategy for women who are } \\
\text { anovulatory to improve fertility and overall pregnancy } \\
\text { rate, but it is associated with an increase in SGA, CS } \\
\text { and NND. }\end{array}$ \\
\hline $\begin{array}{l}\text { Sheiner et al. }{ }^{23} \\
\text { (2004) }\end{array}$ & - None & $\begin{array}{l}\text { - Higher PROM, } \\
\text { labour induction, } \\
\text { failed induction, IUGR } \\
\text { and CS }\end{array}$ & $\begin{array}{l}\text { No change in GDM or perinatal complications after } \\
\text { BS. }\end{array}$ \\
\hline $\begin{array}{l}\text { Dell'Agnollo et al. } \\
(2015)\end{array}$ & $\begin{array}{l}\text { - Lower GDM, PE, PIH and } \\
\text { sleep apnoea }\end{array}$ & $\begin{array}{l}\text { - Lower birth weight } \\
\text { - Higher CS and } \\
\text { preterm birth }\end{array}$ & $\begin{array}{l}\text { Except for a high index of SGA, it can be concluded } \\
\text { that BS is safe. Growth in children was found to be } \\
\text { adequate. Although changes in speech and development } \\
\text { were detected, no factor was found to have an assoc- } \\
\text { iation with pregnancy after BS. }\end{array}$ \\
\hline $\begin{array}{l}\text { Stephansson et al. } .^{9} \\
(2017)\end{array}$ & $\begin{array}{l}\text { - Lower risk of labour } \\
\text { induction, post-term } \\
\text { pregnancy, obstetrical anal } \\
\text { sphincter injuries, PPH and } 5 \\
\text { minutes Apgar score }\end{array}$ & $\begin{array}{l}\text { - Higher SGA and } \\
\text { preterm births }\end{array}$ & $\begin{array}{l}\text { BS is associated with a decrease in adverse pregnancy } \\
\text { outcomes. }\end{array}$ \\
\hline $\begin{array}{l}\text { Getahun et al. }{ }^{60} \\
(2013)\end{array}$ & $\begin{array}{l}\text { - Lower PE, abruptio placenta, } \\
\text { chorioamnionitis, GDM, fetal } \\
\text { distress, labour induction, } \\
\text { macrosomia, RDS and } \\
\text { neonatal sepsis }\end{array}$ & $\begin{array}{l}\text { - Higher surgical site } \\
\text { wound, infection and } \\
\text { CS }\end{array}$ & $\begin{array}{l}\text { The results suggest that BS may be associated with } \\
\text { selected adverse perinatal outcomes. Targeted nutri- } \\
\text { tional intervention and intrapartum care are key } \\
\text { elements for a good perinatal outcome. }\end{array}$ \\
\hline $\begin{array}{l}\text { Costa et al. } \\
(2018)\end{array}$ & $\begin{array}{l}\text { - Lower GDM, HTN, PPH } \\
\text { and CS }\end{array}$ & $\begin{array}{l}\text { - Higher aortic } \\
\text { dilatation, } \\
\text { microphthalmia, } \\
\text { RDS, necrotising } \\
\text { enterocolitis and } \\
\text { preterm births }\end{array}$ & $\begin{array}{l}\text { Neonatal outcome may vary depending upon the BS } \\
\text { technique. Gastric banding is associated with less risk } \\
\text { of malnutrition compared to other types of surgeries, } \\
\text { so nutritional evaluation is important to avoid a devast- } \\
\text { ating neonatal outcome. }\end{array}$ \\
\hline $\begin{array}{l}\text { Harreiter et al. }{ }^{31} \\
(2018)\end{array}$ & $\begin{array}{l}\text { - Lower GDM, PE, PIH, CS, } \\
\text { macrosomia, SGA, IUGR and } \\
\text { venous thrombosis } \\
\text { • Higher vaginal births and } \\
\text { vaginal birth after previous CS }\end{array}$ & - None & $\begin{array}{l}\text { Obstetrical complications decrease after gastric band } \\
\text { surgeries. }\end{array}$ \\
\hline $\begin{array}{l}\text { Zozzaro-Smith } \\
\text { et al. }{ }^{28}(2016)\end{array}$ & $\begin{array}{l}\text { - Lower macrosomia, CS, } \\
\text { GDM, PE and PIH }\end{array}$ & - None & $\begin{array}{l}\text { Pregnancy after BS is safe. Perinatal outcome is comp- } \\
\text { arable to the general population. }\end{array}$ \\
\hline $\begin{array}{l}\text { Falcone et al. } .^{34} \\
(2018)\end{array}$ & $\begin{array}{l}\text { - Higher fertility } \\
\text { - Lower macrosomia }\end{array}$ & $\begin{array}{l}\text { - Parentral nutrition } \\
\text { needed by } 2.5 \% \\
\text { - Slightly higher SGA }\end{array}$ & $\begin{array}{l}\text { Pregnancy rate increases after BS but might require } \\
\text { nutritional supplementation. }\end{array}$ \\
\hline
\end{tabular}

GDM = gestational diabetes mellitus; HTN = hypertensive disorders in pregnancy; $P P H=$ postpartum haemorrhage; $P E=$ pre-eclampsia; $S G A=$ small for gestational age; IUGR = intrauterine growth restriction; $B S=$ bariatric surgery; $C S=$ caesarean section; $N N D=$ neonatal death; $P R O M=$ premature rupture of membranes; $P I H$ = pregnancy-induced hypertension; $R D S=$ respiratory distress syndrome.

obesity who have not undergone BS (3.2\% versus $7.6 \%$; $P=0.004){ }^{19}$

Sheiner et al. found an increased rate of IUGR in pregnancies after BS compared to those without BS (5\% versus $2 \% ; P=0.001$ ). However, after multivariate analysis this finding became insignificant (OR: 1.4; $P=$ 0.063). ${ }^{23}$ Patel et al. also found a significant reduction in fetal macrosomia after BS; nevertheless, they also noted an increased rate of SGA fetuses among women
post-BS compared to those who had never undergone BS $(11.5 \%$ versus $0.5 \%$; $P<0.001) .{ }^{24}$ Dixon et al. reported no significant difference in birth weight between pregnancies with and without BS. ${ }^{25}$

The timing of pregnancy after BS has not been demonstrated to have an impact on birth weight. Dao et al. reported on 34 patients who became pregnant after BS between 2001 and 2004; there was no significant difference between birth weight among 21 women 
Table 2: Summary of previous studies related to nutritional deficiencies and fetomaternal outcomes after bariatric surgery ${ }^{16,26,27,36,43-46,48,49}$

\begin{tabular}{|c|c|c|c|c|}
\hline $\begin{array}{l}\text { Author and year } \\
\text { of publication }\end{array}$ & Maternal complication & Fetal complication & $\begin{array}{l}\text { Long-term } \\
\text { fetomaternal } \\
\text { complication }\end{array}$ & $\begin{array}{c}\text { Interval } \\
\text { between } \\
\text { BS and } \\
\text { pregnancy }\end{array}$ \\
\hline $\begin{array}{l}\text { Cools et al. }{ }^{26} \\
(2006)\end{array}$ & $\begin{array}{l}\text { - Nutritional deficiencies } \\
\text { - Hypoplastic anaemia }\end{array}$ & $\begin{array}{l}\text { - Multiple congenital anomalies } \\
\text { - Iron deficiency anaemia } \\
\text { - Preterm labour }\end{array}$ & $\begin{array}{l}\text { - Blindness } \\
\text { - Epilepsy } \\
\text { - Deafness }\end{array}$ & 2 years \\
\hline $\begin{array}{l}\text { Monkhouse et } \\
\text { al. }^{48}(2009)\end{array}$ & $\begin{array}{l}\text { - Preterm labour } \\
\text { - Anaemia }\end{array}$ & $\begin{array}{l}\text { - Preterm delivery } 22 \text { gestational } \\
\text { weeks }\end{array}$ & - Perinatal death & 3 years \\
\hline $\begin{array}{l}\text { Vrebosch et al. }{ }^{49} \\
(2012)\end{array}$ & $\begin{array}{l}\text { - Preterm labour } 27 \\
\text { gestational weeks } \\
\text { - Iron deficiency anaemia }\end{array}$ & $\begin{array}{l}\text { - Hydrocephalus } \\
\text { - Hypoplastic corpus callosum } \\
\text { - Atrophy of cerebral cortex }\end{array}$ & $\begin{array}{l}\text { - Visual disturbances } \\
\text { - Deafness } \\
\text { - Growth restriction }\end{array}$ & 5 years \\
\hline $\begin{array}{l}\text { Adam et al. }{ }^{36} \\
(2017)\end{array}$ & $\begin{array}{l}\text { - Abdominal pain at } 33 \\
\text { gestational weeks }\end{array}$ & $\begin{array}{l}\text { - Congenital abnormalities } \\
\text { - Hydrocephalus } \\
\text { - Coagulation problems } \\
\text { - Cerebral haemorrhage }\end{array}$ & - Perinatal death & 3 years \\
\hline $\begin{array}{l}\text { Kaska et al. }{ }^{27} \\
(2013)\end{array}$ & $\begin{array}{l}\text { - Thiamine deficiency } \\
\text { - Hyperemesis gravidarum } \\
\text { - Wernicke encephalopathy } \\
\text { - Megaloblastic anaemia }\end{array}$ & $\begin{array}{l}\text { - Neural tube defects } \\
\text { - Preterm delivery anaemia }\end{array}$ & $\begin{array}{l}\text { - Deafness } \\
\text { - Delay in speech }\end{array}$ & 3-24 months \\
\hline $\begin{array}{l}\text { Guelinckx et al. }{ }^{16} \\
(2008)\end{array}$ & - Vitamin K deficiency & - Cerebral haemorrhage & - Perinatal death & 2 years \\
\hline $\begin{array}{l}\text { Smets et al. }{ }^{43} \\
(2006)\end{array}$ & - Vitamin A deficiency & - Bilateral microphthalmia & - Delay in speech & 8 years \\
\hline $\begin{array}{l}\text { Devlieger et al. }{ }^{44} \\
(2014)\end{array}$ & $\begin{array}{l}\text { - Vomiting } \\
\text { - Iron deficiency anaemia } \\
\text { - Vitamin A deficiency }\end{array}$ & $\begin{array}{l}\text { - Neural tube defects } \\
\text { - Preterm birth } \\
\text { - Intracranial haemorrhage }\end{array}$ & - Epilepsy & $3-24$ months \\
\hline $\begin{array}{l}\text { Bebber et al. }{ }^{45} \\
(2011)\end{array}$ & $\begin{array}{l}\text { - Vitamin B12 deficiency in } \\
\text { breast milk } \\
\text { - Iron deficiency anaemia }\end{array}$ & - Macrocytic anaemia & - None & 18 months \\
\hline $\begin{array}{l}\text { Pelizzo et al. }{ }^{46} \\
(2014)\end{array}$ & $\begin{array}{l}\text { - Protein nutritional } \\
\text { deficiency } \\
\text { - Malabsorption } \\
\text { - Low fat content in breast } \\
\text { milk }\end{array}$ & $\begin{array}{l}\text { - Neural tube defects } \\
\text { - Iron deficiency anaemia } \\
\text { - Neutropenia }\end{array}$ & - None & 7-24 months \\
\hline
\end{tabular}

$B S=$ bariatric surgery.

who became pregnant within one year compared to 13 women who conceived one year after BS. ${ }^{29}$

\section{MODE OF DELIVERY}

Regarding mode of delivery, BS itself is not an indication for CS. Costa et al. and Harreiter et al. both reported a decrease in CS after BS. ${ }^{30,31}$ Conversely, Sheiner et al. found a higher CS rate after controlling for cofounders (25.2\% versus $12.2 \%$, OR: $2.4 ; P<0.001) .{ }^{23}$ However, case-control studies did not show any significant difference in CS after BS. ${ }^{24,32}$ The American College of Obstetricians and Gynaecologists Committee Opinion showed an increase in CS rates and though this may be due to previous CS, maternal request or other obstetrical indications, data is sparse about increased CS rates following BS. 33,34

\section{NUTRITIONAL DEFICIENCIES}

Nutritional deficiencies are well-recognised complications of BS and may lead to a reduction in vitamin B, fat-soluble vitamins, folic acid, iron and calcium..$^{35,36}$
The underlying aetiological factor is thought to be a decreased production of gastric acid leading to a decreased absorption of micronutrients. ${ }^{37,38}$

Iron, thiamine and vitamins $\mathrm{A}, \mathrm{K}$ and $\mathrm{D}$ deficiencies are common in pregnancies after BS. Wernicke encephalopathy and anaemia may occur due to the deficiency of thiamine and iron, respectively. ${ }^{39}$ Vitamin $\mathrm{D}$ deficiency can lead to bone loss and dental problems in the mother and child. ${ }^{40,41}$ Nutritional deficiencies may also cause fetal malformations and fetal growth restriction. Cools et al's study showed that deficiency of micronutrients, specifically folic acid, vitamin $\mathrm{K}$ and A, can adversely affect the fetus, not only in utero, but also later in life. ${ }^{26}$ Neural tube defects, anaemia, preterm births, cerebral haemorrhage, perinatal death, failure to thrive, blindness, deafness, growth retardation and epilepsy have also been reported in some studies, although more observation and follow-up is needed [Table 2]. ${ }^{26,27,42,43}$

Nutritional deficiencies can be compensated with pre-pregnancy consumption of $5 \mathrm{mg}$ of folic 
acid daily which should be continued until 12 weeks of gestation. Other vitamins, minerals and nutrients should be administered in recommended quantities to avoid further deficiencies. ${ }^{44,45}$

\section{SURGICAL COMPLICATIONS IN PREGNANCY AFTER BARIATRIC SURGERY}

Like other surgical procedures, BS has many complications depending upon the type of surgery. The most common complications of BS include small bowel obstruction, volvulus, intussusception, gastric band erosion, slipping of gastric band, gastric ulcers, stitchline leak and potentially life-threatening peritonitis. ${ }^{46-49}$

Symptoms of BS complications may mimic common symptoms of physiological changes during pregnancy and require vigilant management. Stuart et al's study found a higher rate of laparotomies in pregnancies after BS (1.5\% versus $0.1 \%$, OR: $11.3 \%$, 95\% CI: 6.9-18.5) and higher incidence of intestinal obstruction (1.5\% versus 0.02\%, OR: 34.3, 95\% CI: 11.9-98.7) in Sweden. ${ }^{50}$ A recent case report by Petrucciani et al. showed thrombosis in the small intestine of a 29-year-old pregnant female who had BS six years earlier and presented at 24 weeks of gestation. ${ }^{51}$ She presented with severe abdominal pain and upon ultrasound scan, was found to have fluid collection in her abdomen. Laparotomy was performed by a bariatric and a general surgeon who found ischaemia of the small intestine. The small intestine was resected and a hysterotomy was performed to deliver a stillborn fetus. ${ }^{51}$ Maggard et al's systematic review showed three maternal and five neonatal deaths with surgical intervention in 20 cases during pregnancy after BS. ${ }^{52}$ The majority of these interventions were due to internal hernias; gastric band migration, slipping and erosion have also been reported and some of these cases have had laparoscopic removal of gastric bands. ${ }^{51,52}$

\section{Discussion}

Obesity is increasing exponentially among women of reproductive age. Concurrently, rates of BS are rising as this solution is a favourable option for weight loss among this population.

Dixon et al. found no difference in perinatal outcome in conception occurring within one or two years after BS. ${ }^{25}$ Patel et al. reported an increase in preterm deliveries in pregnancies within one year of BS. ${ }^{24}$ With the current available data, it is advisable to avoid pregnancy for at least one year following BS..$^{53}$

Dao et al. and Roehrig et al. reported fertility improvements in women after BS; the likelihood of unintentional pregnancy was also higher. ${ }^{29,54}$ Therefore, contraceptive options should be discussed with women who have undergone BS, especially considering the questionable absorption of oral contraceptive pills; this is also supported by the American College of Obstetricians and Gynecologists clinical guidelines on pregnancy after BS. ${ }^{33}$

Luck et al's study showed that in pregnancies after BS, there is a reduction in hypertensive disorders in pregnancy, GDM and macrosomic fetuses but it has also been found that there is an increase in IUGR and SGA fetuses. ${ }^{21}$

It should be noted that many studies included in this review are case-control and cohort studies that have variable results and exhibit heterogeneity. Studies about congenital malformations and neonatal outcomes are underpowered with no homogeneity. Some of these studies have used a control group without prior BS. Skull et al. and Bilenka et al. used the patients as their own controls. ${ }^{32,55}$ Cools et al. and Huerta et al. stated that there was no long-term follow-up data for children born to mothers who had BS. ${ }^{26,56}$

Few studies addressed nutritional deficiencies and there is no evidence-based recommended daily nutritional intake requirements for pregnant women who had undergone BS. ${ }^{40,41}$ More detailed studies with long-term follow-up are required to determine the relationship between BS and nutritional deficiencies, congenital malformations, IUGR, SGA and long-term effects on children after birth.

Post-BS pregnancies are high risk and demand careful management by obstetricians, nutritionists and bariatric surgeons. Peri-conceptional, antenatal, intrapartum and postpartum assessment and management are essential in dealing with all issues and complications. ${ }^{56}$ Pre-pregnancyassessments of nutritional status, specifically the intake of folic acid, vitamin B12, calcium and iron, can prevent many complications during the antnatal period.

Early assessment by a senior obstetrician are important in such cases and anomaly scans should be performed to exclude neural tube defects and other fetal malformations. Screening for SGA by ultrasound for fetal growth (growth-curves, amniotic fluid index and umbilical artery Doppler) should be conducted for diagnosis and follow-up. ${ }^{57-60}$ Any abdominal pain in such pregnancies warrants early scanning and involvement of surgical colleagues. There is no contraindication for vaginal births in these pregnancies except for other obstetrical indications.

Postpartum care is routine with additional dietary assessment to avoid nutritional deficiencies in the neonate and breastfeeding must be strongly encouraged. Discussion about future contraception is also particularly important considering the lower absorption of oral contraceptives which might affect their efficacy. 


\section{Conclusion}

The included observational, case-control and cohort studies are suggestive of a decrease in the incidence of GDM, hypertensive disorders in pregnancy and macrosomia in pregnancies after BS. However, there is a lack of robust data regarding the risk of IUGR, fetal anomalies and SGA after BS, necessitating the need for more research. CS rates also remain high following BS and nutritional deficiencies require careful attention to ensure adherence to nutritional supplements in addition to careful monitoring regarding early detection and treatment. Moreover, there is no international consensus regarding the management of post-BS pregnancies due to their novelty, hence an evidence-based guideline is urgently needed. In addition, follow-up studies should focus on obstetrical outcome and longterm neonatal effects in children born to women who have undergone BS prior to their pregnancy.

\section{References}

1. World Health Organization. Noncommunicable Diseases Progress Monitor 2017. Geneva: World Health Organization. P. 211.

2. Guthold R, Ono T, Strong KL, Chatterji S, Morabia A. Worldwide variability in physical inactivity a 51-country survey. Am J Prev Med 2008; 34:486-94. https://doi.org/10.1016/j. amepre.2008.02.013.

3. Nuthalapaty FS, Rouse DJ. The impact of obesity on obstetrical practice and outcome. Clin Obstet Gynecol 2004; 47:898-913. https://doi.org/10.1097/01.grf.0000135358.34673.48.

4. Weindling AM. The confidential enquiry into maternal and child health (CEMACH). Arch Dis Child 2003; 88:1034-7. https://doi.org/10.1136/adc.88.12.1034.

5. Stevens GA, Singh GM, Lu Y, Danaei G, Lin JK, Finucane MM, et al. National, regional, and global trends in adult overweight and obesity prevalences. Popul Health Metr 2012; 10:22. https://doi.org/10.1186/1478-7954-10-22.

6. Michalakis K, Mintziori G, Kaprara A, Tarlatzis BC, Goulis DG. The complex interaction between obesity, metabolic syndrome and reproductive axis: a narrative review. Metabolism 2013; 62:457-78. https://doi.org/10.1016/j.metabol.2012.08.012.

7. Pasquali R, Pelusi C, Genghini S, Cacciari M, Gambineri A. Obesity and reproductive disorders in women. Hum Reprod Update 2003; 9:359-72. https://doi.org/10.1093/humupd/dmg024.

8. Santry HP, Gillen DL, Lauderdale DS. Trends in bariatric surgical procedures. JAMA 2005; 294:1909-17. https://doi.org/10.1001/ jama.294.15.1909.

9. Poirier P, Cornier MA, Mazzone T, Stiles S, Cummings S, Klein S, et al. Bariatric surgery and cardiovascular risk factors: A scientific statement from the American Heart Association. Circulation 2011;123:1683-701.https://doi.org/10.1161/CIR.0b013e3182149099.

10. National Institute for Health Care Excellence. Obesity prevention. Clinical guidance [CG43]. From: https://www.nice.org. uk/guidance/CG43 Accessed: Jun 2019.

11. Park CW, Torquati A. Physiology of weight loss surgery. Surg Clin North Am 2011; 91:1149-61. https://doi.org/10.1016/j. suc.2011.08.009.

12. Merhi ZO. Impact of bariatric surgery on female reproduction. Fertil Steril 2009; 92:1501-8. https://doi.org/10.1016/j.fertns tert.2009.06.046
13. Beard JH, Bell RL, Duffy AJ. Reproductive considerations and pregnancy after bariatric surgery: Current evidence and recommendations. Obes Surg 2008; 18:1023-7. https://doi.org/10.1007/ s11695-007-9389-3.

14. Sjöström L, Peltonen M, Jacobson P, Sjöström CD, Karason K, Wedel $\mathrm{H}$, et al. Bariatric surgery and long-term cardiovascular events. JAMA 2012; 307:56-65. https://doi.org/10.1001/jama.20 11.1914 .

15. Longitudinal Assessment of Bariatric Surgery (LABS) Consortium, Flum DR, Belle SH, King WC, Wahed AS, Berk P, et al. Perioperative safety in the longitudinal assessment of bariatric surgery. N Eng J Med 2009; 361:445-54. https://doi.org/10.10 56/NEJMoa0901836.

16. Guelinckx I, Devlieger R, Beckers K, Vansant G. Maternal obesity: Pregnancy complications, gestational weight gain and nutrition. Obes Rev 2008; 9:140-50. https://doi.org/10.1111/ j.1467-789X.2007.00464.x.

17. Hezelgrave NL, Oteng-Ntim E. Pregnancy after bariatric surgery: A review. J Obes 2011; 2011:501939. https://doi.org/10.1155/20 $11 / 501939$.

18. American College of Obstetricians and Gynecologists. ACOG Committee opinion no. 549: Obesity in pregnancy. Obstet Gynecol 2013; 121:213-17. https://doi.org/10.1097/01.AOG.00 00425667.10377 .60 .

19. Weintraub AY, Levy A, Levi I, Mazor M, Wiznitzer A, Sheiner E. Effects of bariatric surgery on pregnancy outcome. Int J Gynaecol Obstet 2008;103:246-51. https://doi.org/10.1016/j.ij go.2008.07.008.

20. Kwong W, Tomlinson G, Feig DS. Gestational diabetes and other obstetrical outcomes after bariatric surgery: A systematic review and meta-analysis. Can J Diabetes 2016; 40:S18. https://doi.org/10.1016/j.jcjd.2016.08.055.

21. Luck M, Cahill AG, Niu B, Ameel B, Caughey AB. Costeffectiveness of pre- pregnancy bariatric surgery [9C]. Obstet Gynecol 2016; 127:S28-9. https://doi.org/10.1097/01.AOG.00 00483358.01712.af

22. Johansson K, Cnattingius S, Näslund I, Roos N, Trolle Lagerros Y, Granath F, et al. Outcome of pregnancy after bariatric surgery. N Engl J Med 2015; 372:814-24. https://doi.org/10.1056/N EJMoa1405789.

23. Sheiner E, Levy A, Silverberg D, Menes TS, Levy I, Katz M, et al. Pregnancy after bariatric surgery is not associated with adverse perinatal outcome. Am J Obstet Gynecol 2004; 190:1335-40. https://doi.org/10.1016/j.ajog.2003.11.004.

24. Patel JA, Patel NA, Thomas RL, Nelms JK, Colella JJ. Pregnancy outcomes after laparoscopic roux-en-y gastric bypass. Surg Obes Relat Dis 2008; 4:39-45. https://doi.org/10.1016/j.soard.20 07.10.008.

25. Dixon JB, Dixon ME, O'Brien PE. Birth outcomes in obese women after laparoscopic adjustable gastric banding. Obstet Gynecol 2005; 106:965-72. https://doi.org/10.1097/01.AOG.00 00181821.82022 .82 .

26. Cools M, Duval EL, Jespers A. Adverse neonatal outcome after maternal biliopancreatic diversion operation: Report of nine cases. Eur J Pediatr 2006; 165:199-202. https://doi.org/10.1007/ s00431-005-0056-1.

27. Kaska L, Kobiela J, Abacjew-Chmylko A, Chmylko L, Wojanowska-Pindel M, Kobiela P, et al. Nutrition and pregnancy after bariatric surgery. ISRN Obes 2013; 2013:492060. https://doi.org/10.1155/2013/492060.

28. Zozzaro-Smith PE, Bacak S, Conway C, Park J, Glantz JC, Thornburg LL. Association between obesity during pregnancy and the adequacy of prenatal care. Matern Child Health J 2016; 20:158-63. https://doi.org/10.1007/s10995-015-1815-x.

29. Dao T, Kuhn J, Ehmer D, Fisher T, McCarty T. Pregnancy outcome after gastric-bypass surgery. Am J Surg 2006; 192:762-6. https://doi.org/10.1016/j.amjsurg.2006.08.041. 
30. Costa MM, Belo S, Souteiro P, Neves JS, Magalhães D, Silva RB, et al. Pregnancy after bariatric surgery: Maternal and fetal outcomes of 39 pregnancies and a literature review. J Obstet Gynaecol Res 2018; 44:681-90. https://doi.org/10.1111/jog.13574.

31. Harreiter J, Schindler K, Bancher-Todesca D, Göbl C, Langer F, Prager G, et al. Management of pregnant women after bariatric surgery. J Obes 2018; 2018:4587064. https://doi.org/10.1155/20 $18 / 4587064$

32. Skull AJ, Slater GH, Duncombe JE, Fielding GA. Laparoscopic adjustable banding in pregnancy: Safety, patient tolerance and effects on obesity-related pregnancy outcomes. Obes Surg 2004; 14:230-5. https://doi.org/10.1381/096089204322857618.

33. American College of Obstetricians and Gynecologists. ACOG practice bulletin no. 105: Bariatric surgery and pregnancy. Obstet Gynecol 2009; 113:1405-13. https://doi.org/10.1097/ AOG.0b013e3181ac0544.

34. Falcone V, Stopp T, Feichtinger M, Kiss H, Eppel W, Husslein PW, et al. Pregnancy after bariatric surgery: A narrative literature review and discussion of impact on pregnancy management and outcome. BMC Pregnancy Childbirth 2018; 18:507. https://doi.org/10.1186/s12884-018-2124-3.

35. Poitou Bernert C, Ciangura C, Coupaye M, Czernichow S, Bouillot JL, Basdevant A. Nutritional deficiency after gastric bypass: Diagnosis, prevention and treatment. Diabetes Metab 2007; 33:13-24. https://doi.org/10.1016/j.diabet.2006.11.004.

36. Adam S, Ammori B, Soran H, Syed AA. Pregnancy after bariatric surgery: Screening for gestational diabetes. BMJ 2017; 356:j533. https://doi.org/10.1136/bmj.j533.

37. Kumari A, Nigam A. Bariatric surgery in women: A boon needs special care during pregnancy. J Clin Diagn Res 2015; 9:QE01-5. https://doi.org/10.7860/JCDR/2015/14258.6802.

38. Mancini MC. Dealing with diabetes and pregnancy following bariatric surgery: A double-edged sword? Arch Endocrinol Metab 2016; 60:299-302. https://doi.org/10.1590/2359-3997000000181.

39. Slater C, Morris L, Ellison J, Syed AA. Nutrition in pregnancy following bariatric surgery. Nutrients 2017; 9:E1338. https://doi.org/10.3390/nu9121338.

40. Avgerinos DV, Llaguna $\mathrm{OH}$, Seigerman $\mathrm{M}$, Lefkowitz AJ, Leitman IM. Incidence and risk factors for the development of anemia following gastric bypass surgery. World J Gastroenterol 2010; 16:1867-70. https://doi.org/10.3748/wjg.v16.i15.1867.

41. Van Mieghem T, Van Schoubroeck D, Depiere M, Debeer A, Hanssens M. Fetal cerebral hemorrhage caused by vitamin K deficiency after complicated bariatric surgery. Obstet Gynecol 2008; 112:434-6. https://doi.org/10.1097/AOG.0b013e3181649e7b.

42. Dagan SS, Goldenshluger A, Globus I, Schweiger C, Kessler Y, Sandbank GK, et al. Nutritional recommendations for adult bariatric surgery patients: Clinical practice. Adv Nutr 2017; 8:382- 94. https://doi.org/10.3945/an.116.014258.

43. Smets KJ, Barlow T, Vanhaesebrouck P. Maternal vitamin A deficiency and neonatal microphthalmia: Complications of biliopancreatic diversion? Eur J Pediatr 2006; 165:502-4. https://doi.org/10.1007/s00431-006-0120-5.

44. Devlieger R, Guelinckx I, Jans G, Voets W, Vanholsbeke C, Vansant G. Micronutrient levels and supplement intake in pregnancy after bariatric surgery: A prospective cohort study. PLoS One 2014; 9:e114192. https://doi.org/10.1371/journal. pone. 0114192

45. Bebber FE, Rizzolli J, Casagrande DS, Rodrigues MT, Padoin AV, Mottin CC, et al. Pregnancy after bariatric surgery: 39 pregnancies follow-up in a multidisciplinary team. Obes Surg 2011; 21:1546-51. https://doi.org/10.1007/s11695-010-0263-3.
46. Pelizzo G, Calcaterra V, Fusillo M, Nakib G, Ierullo AM, Alfei A, et al. Malnutrition in pregnancy following bariatric surgery: Three clinical cases of fetal neural defects. Nutr J 2014; 13:59. https://doi.org/10.1186/1475-2891-13-59.

47. Hung TH, Hsieh TT. Pregestational body mass index, gestational weight gain, and risks for adverse pregnancy outcomes among Taiwanese women: A retrospective cohort study. Taiwan J Obstet Gynecol 2016; 55:575-81. https://doi.org/10.1016/j. tjog.2016.06.016

48. Monkhouse SJW, Morgan JDT, Norton SA. Complications of bariatric surgery: Presentation and emergency management - A review. Ann R Coll Surg Engl 2009; 91:280-6. https://doi.org/10.13 08/003588409X392072.

49. Vrebosch L, Bel S, Vansant G, Guelinckx I, Devlieger R. Maternal and neonatal outcome after laparoscopic adjustable gastric banding: A systematic review. Obes Surg 2012; 22:1568-79. https://doi.org/10.1007/s11695-012-0740-y.

50. Stuart A, Källen K. Risk of abdominal surgery in pregnancy among women who have undergone bariatric surgery. Obstet Gynecol 2017; 129:887-95. https://doi.org/10.1097/AOG.0000000000001975.

51. Petrucciani N, Debs T, Ciampi D, Massalou D, Kassir R, Amor IB, et al. Rare cause of small bowel ischemia during pregnancy after roux-en-y gastric bypass. Obes Surg 2017; 27:1879-81. https://doi.org/10.1007/s11695-017-2676-8.

52. Maggard MA, Yermilov I, Li Z, Maglione M, Newberry S, Suttorp $M$, et al. Pregnancy and fertility following bariatric surgery: A systematic review. JAMA 2008; 300:2286-96. https://doi.org/10.1001/jama.2008.641.

53. Skubleny D, Switzer NJ, Gill RS, Dykstra M, Shi X, Sagle MA, et al. The impact of bariatric surgery on polycystic ovary syndrome: A systematic review and meta-analysis. Obes Surg 2016; 26:169-76. https://doi.org/10.1007/s11695-015-1902-5.

54. Roehrig HR, Xanthakos SA, Sweeney J, Zeller MH, Inge TH. Pregnancy after gastric bypass surgery in adolescents. Obes Surg 2007; 17:873-7. https://doi.org/10.1007/s11695-007-9162-7.

55. Bilenka B, Ben-Shlomo I, Cozacov C, Gold CH, Zohar S. Fertility, miscarriage and pregnancy after vertical banded gastroplasty operation for morbid obesity. Acta Obstet Gynecol Scand 1995; 74:42-4. https://doi.org/10.3109/00016349509009942.

56. Huerta S, Rogers LM, Li Z, Heber D, Liu C, Livingstone EH. Vitamin A deficiency in a newborn resulting from maternal hypovitaminosis A after biliopancreatic diversion for the treatment of morbid obesity. Am J Clin Nutr 2002; 76:426-9. https://doi.org/10.1093/ajcn/76.2.426.

57. Dell'Agnolo CM, Cyr C, de Montigny F, de Barros Carvalho MD, Pelloso SM. Pregnancy after bariatric surgery: Obstetric and perinatal outcomes and the growth and development of children. Obes Surg 2015; 25:2030-9. https://doi.org/10.1007/s11695015-1668-9.

58. Dalfrà MG, Busetto L, Chilelli NC, Lapolla A. Pregnancy and foetal outcome after bariatric surgery: A review of recent studies. J Matern Fetal Neonatal Med 2012; 25:1537-43. https://doi.org/10.3109/14767058.2012.663829.

59. Stephansson O, Johansson K, Näslund I, Neovius M. Delivery outcomes after bariatric surgery: 502. Am J Obstet Gynecol 2017; 216:S296-7. https://doi.org/10.1016/j.ajog.2016.11.237.

60. Getahun D, Coelman K, Fassett M, Wing D, Jacobsen S. 663: Perinatal outcomes after bariatric surgery. Am J Obstet Gynecol 2013; 208:S280. https://doi.org/10.1016/j.ajog.2012.10.829. 